
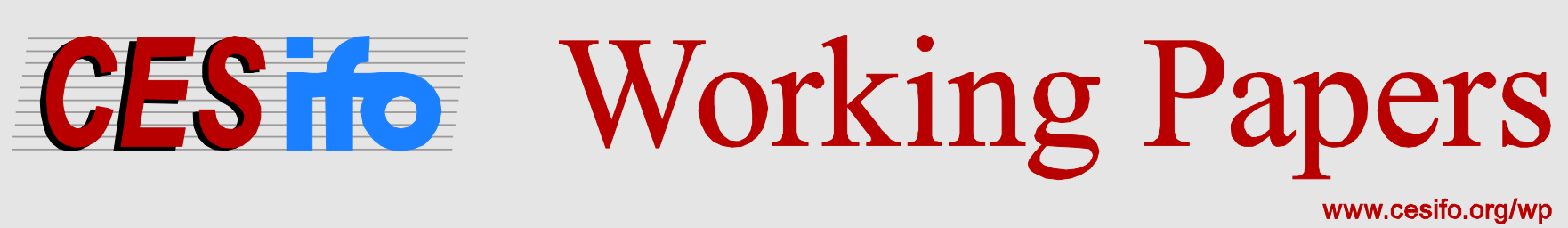

\title{
Soft Paternalism, Merit Goods, and Normative Individualism
}

\author{
Gebhard Kirchgässner
}

\section{CESIFO WORKING PAPER NO. 4688 \\ CATEgORY 1: Public FinANCE \\ MARCH 2014}
An electronic version of the paper may be downloaded
- from the SSRN website: Www.SSRN.com
- from the RePEc website: Www.RePEc.org
- from the CESifo website: www.CESifo-group.org/wp

\section{CESifo}




\title{
Soft Paternalism, Merit Goods, and Normative Individualism
}

\begin{abstract}
Paternalism is an attempt to influence individuals' decisions for their own benefit, even if there are no third parties involved. This seems to contradict normative individualism, which provides the general orientation to our modern democracies. Soft or libertarian paternalism accepts the necessity of paternalism due to the existence of behavioural anomalies, but intends to apply only such measures that do not restrict the decision leeway of individuals. Nevertheless, the same objections that can be raised against its strong version can also be raised against soft paternalism. On the other hand, as soon as we accept that human beings are able to reflect not only about their actions but also about the preferences guiding their actions, there is no longer a necessary contradiction between paternalism and normative individualism. As far as we know today, the possibilities to successfully apply soft paternalistic measures are rather limited. On the other hand, while some criticisms of it are justified, others largely overshoot the mark and seem to be at least partly ideologically motivated.
\end{abstract}

JEL-Code: H420, D630, D720.

Keywords: libertarian paternalism, soft paternalism, merit goods, normative individualism, constitutional economics, democracy.

\author{
Gebhard Kirchgässner \\ Institute for Advanced Study / Berlin \\ \& University of St. Gallen \\ SIAW-HSG \\ Bodanstrasse 8 \\ Switzerland - 9030 St. Gallen \\ gebhard.kirchgaessner@unisg.ch
}

February 2014. A previous shorter German version has been published as G. KIRCHGÄSSNER (2013). I thank Mitch Cohen for editing the paper in English. - (C) Gebhard Kirchgässner. 
Introduction

[1] Whether we consider mandatory social insurance, subsidies for operas and theatres or the provision of information for consumers by government agencies: paternalism is omnipresent. From a liberal perspective, however, it can hardly be justified in the face of mature citizens; it contradicts - at least prima facie - the principle of normative individualism that has dominated our occidental culture since the period of the Enlightenment. One of its basic principles is that the preferences (values) of the autonomous individuals are the only ones that should be socially relevant. Given this background, governmental interventions demand special justifications. These are typically provided by reference to external effects or insufficient provision of public goods by markets with (exclusively) private agents. Correspondingly, such interventions are not considered paternalistic, because individuals' actual preferences are accepted, even if the individuals are prevented from acting in accordance with these preferences. The aim is to prevent negative effects on third parties, and this should result in a social outcome that is finally acceptable for (nearly) all of those affected.

[2] This is different whenever we consider merit goods in the sense of R. A. MusGrave (1957). In these situations, negative effects on third parties are not relevant for government acting. The aim is to influence citizens in such a way that - for their own good - they do not follow their actual preferences, but behave as far as possible in the way intended by the authority that takes the policy measures. The justification given by R. A. MusgraVE (1957, p. 341) for merit goods is hardly compatible with liberal principles, because policy measures are proposed that are intended to lead to results in conflict with the preferences of the individuals involved.

[3] Behind the liberal concept there is the vision of mature and enlightened individuals who by themselves are able to act in accordance with their interests and who take their decisions in accordance with these interests and the available alternatives autonomously. This vision provides also the philosophical background for traditional (non-socialist) economics. This is hardly astonishing, because economics is also a 'child' of the period of the Enlightenment and still imbedded in this tradition. At least as normative guideline for individual behaviour, this vision has hardly lost any of its attractiveness. A quite different question is, however, the degree to which individuals really behave in accordance with this vision in their day-to-day life. In this respect, during recent decades, Behavioural Economics has presented a whole series of well-documented 'behavioural anomalies', i.e. behavioural patterns that are hardly compatible with this vision. ${ }^{1)}$ To the degree that this is the case, the question of merit goods might demand new answers.

[4] A standard example of such an anomaly is documented in connection with '401(k) accounts' in the U.S. old age pension system. ${ }^{2)}$ The question is whether companies should enrol new employees automatically in this system and give them the opportunity of opting out, or

1. On this, see for example R. H. ThALER (1992) as well as G. KIRCHGÄSSNER (2013, pp. 269ff.).

2. On this, see for example B. D. BERnhEIM, A. FrADKIN and I. POPOV (2011). - The labelling ‘401(k)’ stems from the corresponding definition of the U.S. finance department. For income that is paid into these accounts, social security payments have to be made, but this income is not taxed. Contributions are voluntary. Taxes are only due when the insured receive payments later on. (This arrangement corresponds to the Swiss pension system.) 
only offer the possibility of enrolment. If individuals were fully rational, there should be no difference: they have in both cases the same information and have to decide whether to accept this offer or not. The only difference is where to make the cross on the corresponding form, for enrolment or for opting out; there is neither a difference with respect to transactions costs nor with respect to information.

[5] There are, nevertheless, huge differences with respect to participation in such programmes. B. C. MAdRiAn and D. F. SHEA (2001) show in a case study for a company that participation is significantly higher whenever there is automatic enrolment. ${ }^{3)}$ At the beginning, the saving rate increases by about 50 per cent. This effect is, however, not sustainable, because if there is no automatic enrolment, the participation rate increases continuously and after about three years reaches the more or less constant rate of those who were enrolled automatically. Nevertheless, the amounts of the savings during this period are quite different, and this can have a significant impact on the old age pension later on.

[6] One possible interpretation of this result is that the company provides the status quo and the employees are subject to a status quo bias. ${ }^{4)}$ It might also be seen as an effect of framing. ${ }^{5)}$ In any case, this example shows that the default option, i.e. the arrangement that is proposed in the beginning and that will come into effect if the individual does not explicitly demand another solution, has a considerable impact.

[7] Another well-known fact is that we like to postpone unpleasant business to 'tomorrow'. If we were fully rational, we would not behave in this way. It is of course rational to discount future events. The discount rate should, however, not be too high; it should approximately correspond to the market interest rate, because this reflects the average time preference of the individuals. But independent of how high this rate might ever be, it should be constant over time. The relation between the weight of an event in eleven years compared to one in ten years should be the same as the weight of an event next year compared to one today. In reality, however, there are huge disparities: we use a very high discount rate for events that are close, but very low ones for events in the far future. In an investigation of the saving behaviour of American households, D. LAIBSON, A. REPETTO and J. TOBACMAN (2007) estimated implicit discount rates. According to their results, the implicit short-run discount rate is about 40 per cent, but the long-run 4.3 per cent. While the latter is close to the market interest rate and, therefore, corresponds to traditional economic theory, the very high short-run rate strongly contradicts this theory.

[8] It is debated whether such results can justify paternalistic measures. It is hardly questioned that such measures can be justified for immature people. This starts with the education of children and goes on to the care given to old people who no longer have a sound mind. If we ignore (parts of) the anti-authoritarian movement of the sixties and seventies of the last century that proposed laissez-faire pedagogics, ${ }^{6)}$ hardly anybody will strictly contradict pater-

3. J. J. CHOI et al. (2003) get similar results for three different companies. Theoretical explanations are given by J.J. CHOI et al. (2003a).

4. On the status quo bias see W.F. SAMUELSOn and R. ZECKHAUSER (1988) as well as R. H. THALER (1992, pp. 63ff).

5. On framing effects see A. TVErSKY and D. KAHneman $(1981,1987)$ as well as V. STOCKE (2002).

6. On anti-authoritarian pedagogics see, for example, F. КоCH (2000, pp. 9ff.). 
nalism toward underage children, and we necessarily behave paternalistically toward mentally deranged people.

[9] Paternalism might be a general characteristic trait of human beings. Most of us are tempted to influence the preferences of others, whenever or not we believe that this is in their own interest and whenever we are able to do so. This is quite apparent in the process of socialisation, but quite often also when we make charitable contributions. Charitable organisations utilise this by proposing concrete projects. They expect - and quite often correctly - that this leads to higher contributions. We are normally more willing to give a beggar a bowl of soup than the corresponding amount of money, because we fear that he might use to money to buy alcohol. This shows that whenever we give money to a poor man, we like to prescribe how he should spend it. ${ }^{7}$ )

[10] That people are paternalistic toward other people is one issue, but whether the government should employ paternalistic measures is another one. This can be demonstrated with respect to compulsory schooling. That parents send their children to school is hardly questioned. That governments demand that children go to school, might be questioned. And that only public or publicly authorised schools are allowed is definitely questioned. Also historically, these three aspects have not always been combined. When, for example, compulsory schooling was introduced in Prussia in 1817, this was seen as a duty of the local communities to offer public education. Public schools were the rule, but in specific situations it was possible for parents to educate their children at home. Germany has had a strict obligation to go to a public or publicly authorised school only since $1938 .^{8)}$

[11] Using prescriptions and prohibitions, however, the government is not only paternalistic toward children and mentally handicapped people, but also toward mature adults, for example by prescribing a specific kind of old age insurance or by prohibiting trade with and in most cases also consumption of specific drugs (while at the same time allowing consumption of and trade with other drugs). In specific areas, it thereby deliberately prevents individuals from being able to freely decide what to do.

[12] Thus, the question is how such measures can be justified. Their simple existence does not justify them, but the fact that they are hardly compatible with a certain vision of human beings neither eliminates them nor implies that they cannot be justified. In the following, we first discuss paternalism in some more detail (Section 2) before we discuss a possible justification in Section 3. Section 4 shows possible applications of soft paternalism, while problems and possible objections are discussed in Section 5. While some of the criticisms of it are justified, others largely overshoot the mark and seem at least partly to be ideologically motivated and hardly compatible with democratic principles (Section 6).

7. From a (traditional) economic perspective, this tends to be inefficient, because the poor man might reach a higher utility level if he is free to use this money. However, W. W. POMMEREHNE (1975) has shown that such a conditional transfer might be better for the recipient if this increases willingness to make voluntary contributions.

8. Other countries, for example the United States, do not impose such an obligation. There, mandatory schooling is still seen as an obligation to offer public education. On the history of mandatory education in Germany, see, for example, A. Mors (1986). 


\section{Public Paternalism vs. Normative Individualism}

[13] If we consider all possible paternalistic measures, we can distinguish three variants:

(i) Strong (or hard) paternalism. The government uses prescriptions and prohibitions. Examples are mandatory insurances or prohibitions of trade with and consumption of specific drugs.

(ii) Medium paternalism. The government uses taxes or subsidies. Examples are tobacco taxes ('sin taxes') or subsidies for cultural institutions.

(iii) Soft (or libertarian) paternalism. Here, the provision and suitable presentation of information is at stake. The classical example is the 401(k) accounts in the U.S. old age pension system of the United States. ${ }^{9)}$

While strong paternalism intends to strictly eliminate some behaviour, medium paternalism only makes it more (or less) costly, while soft paternalism operates only via information. It is trivial that the transition between the different variants is sometimes (and perhaps even often) fluid, but this does not affect our arguments. Crucial for all kinds of paternalism is that the manipulation of individuals to improve their own wellbeing is at stake, not the rights or interests of third parties.

[14] It is crucial for the concept of soft paternalism that the possibility for a person's own decisions is given. The underlying assumption is that it is possible to distinguish between 'true' (long-run) and 'actual' (short-run) preferences, and that the latter might be biased by preference anomalies. The individuals' true but not necessarily also their actual preferences are respected. The intent is to overcome the differences between these two kinds of preferences by eliminating informational asymmetries and/or by providing soft incentives, 'nudges', not by hard incentives like taxes or prohibitions. ${ }^{10)}$ The incentives should work asymmetrically: they should help those who are subject to decision anomalies to overcome these, but they should imply no or at least only very light burdens on those who are fully rational. Such biases between true and actual preferences can also be eliminated or at least mitigated by legal regulations. ${ }^{11)}$

[15] Providing information is also a means of soft paternalism, even if it does not play a central role in this concept. Here, too, the intention is to improve the decisions of individuals, in this case by elimination of informational asymmetries. Again, impacts on third parties do not play a role in the justification of such measures. ${ }^{12)}$

9. On the introduction of soft paternalism, see for example G. LOEWENSTEIN and E. HAISLEY (2008), who consider this a new normative economics. The term libertarian paternalism was coined by von C.R. SUNSTEIN and R. H. ThAlER (2003). On this, see also R. H. THALER and C. R. SunSTEIN (2003). - A different distinction between hard and soft paternalism with reference to J. FEINBERG (1986) is, for example, provided by T. M. Pope (2004), who also defends this kind of hard paternalism. On the position of J. FEINBERG, see also R. J. ARNESON (2005).

10. On this in particular, see C. JOLLS and C.R. SUNSTEIN (2006).

11. On this, see also R.H. Thaler and C.R. Sunstein (2008), as well as T. GinsBurG, J.S. MASUR and R.H. MCADAMS (2013), who suggest temporary law as another kind of nudge.

12. H. BECK (2010, pp. 50f.) is thus wrong when he denies that the elimination of informational asymmetries is also an element of soft paternalism. 
[16] Independent of whether paternalism is 'soft' or 'hard', the basic problem how such measures can be justified remains, even if this problem might be less pressing in the case of soft paternalism. There is - at least prima facie - a conflict between applying such measures and the principle of normative individualism. Some of these measures can, of course, be justified by referring to external effects and/or distributional arguments. This holds, for example, for mandatory liability insurances for motor vehicles, which is to ensure that compensation payments can be made for damages resulting from car accidents. A similar argument can be brought forward for a mandatory old age pension system. It is to prevent the need for some individuals be subsidised by the community (by taxpayers' money) because they did not prepare for a pension income for the time after their retirement. ${ }^{13)}$ This argument does, however, no longer hold whenever the pension prescribed by the government exceeds the subsistence level. Mature, autonomous individuals, the counter arguments goes, should have the liberty to decide for themselves when and how to spend their life income as long as they do not generate negative external effects. Consequently, it is sometimes demanded to abolish government regulations that require pension payments exceeding those needed to provide the subsistence level. ${ }^{14)}$

[17] The paternalistic state, however, not only employs prescriptions and prohibitions, but also changes relative prices, even in situations in which no external benefits or costs have to be compensated. For example, besides the prohibition to sell alcoholic beverages to adolescents, taxes are imposed on such beverages as well as on cigarettes in order to reduce their consumption by adults. Part of these taxes might be justified by external costs; for example, cigarette taxes might be justified by the costs the community has to bear resulting from diseases caused by smoking. And gasoline taxes are commonly justified by the external effects of road traffic, even if opinions greatly differ on how large (or small) these costs are. ${ }^{15)}$ Subsidising inoculations might be justified in a similar way; whenever a large part of the population is immunised against a disease the rest of the population is also protected.

[18] Subsidising opera houses or theatres can, however, hardly be justified along this line. ${ }^{16)}$ It might be interpreted as rent seeking by the middle-classes (or, more precisely, of a special group within the middle-class that sees itself as the cultural elite) at the expense of the upper class and those members of the lower classes who pay taxes. Members of the upper class are able to buy non-subsidised tickets; they might lose more by increased (progressive) taxes than they win by the subsidies. Members of the lower classes rarely go to the theatre and even less to operas, but with their taxes they share some of this burden. ${ }^{17)}$ Members of the middle class,

13. Consistent with this argument, the first column of the Swiss old age pension system, the Alters- und Hinterlassenenversicherung (AHV), covers only the subsistence level. (This, of course, holds only for the maximum pension. Whenever somebody receives less than this maximum and does not have additional income and/or wealth, (s)he is entitled to receive additional payments in order to guarantee the subsistence level.)

14. On this, see for example D. DE PURY, H. HAUSER and B. SCHMid (1995, pp. 62ff.).

15. On estimations of the external effects of road traffic, see for example, E. QUINET (2004).

16. The revenue that the 144 German theatre and opera houses took in through ticket sales covered only about 17 per cent of total expenditure in the season 2008/2009. On average, each ticket was subsidised by $€$ 99.31. Source of the data: Statistical Yearbook 2011 for Germany, Table 7.6, p. 180.

17. Those members of the lower classes who, due to their low income, do not have to pay direct taxes might not be directly affected. They might, however, be affected indirectly whenever, in order to finance these 
who show the largest demand for these cultural events, on the other hand, gain by these subsidies because the price reduction of the tickets largely outweighs the additional tax burden. They also attend operas and theatres more often than if there were no such subsidies. ${ }^{18)}$ There are, of course, also attempts to justify these subsidies, but they are hardly convincing. ${ }^{19)}$ At least, the aspect of redistribution in favour of the middle class can hardly be justified.

[19] Discussing these problems for those goods and services whose consumption the government tries to influence by changing relative prices, even if there are no external effects, R.A. MusgraVE (1957, p. 341) introduced the term “merit wants”. (Today we rather speak of merit goods.) He describes this phenomenon, but he does not find a convincing justification for such governmental interventions. This holds, at least as long as we accept the liberal conviction that the citizens themselves know best what is good or bad for them and that even a democratically legitimised government does not have the right to judge their convictions.

[20] Consequently, liberal thinkers have argued against such interventions. In On Liberty, JOHN STUART MILL asks rather rhetorically:

"If protection against themselves is confessedly due to children and persons under age, is not society equally bound to afford it to persons of mature years who are equally incapable of self-government? If gambling, or drunkenness, or incontinence, or idleness, or uncleanliness, are as injurious to happiness, and as great a hindrance to improvement, as many or most of the acts prohibited by law, why (it may be asked) should not law, so far as is consistent with practicability and social convenience, endeavour to repress these also?" (1859, p. 305),

but he insists that governmental interventions are only justified if interests of others are affected:

„As soon as any part of a person's conduct affects prejudicially the interests of others, society has jurisdiction over it, and the question whether the general welfare will or will not be promoted by interfering with it, becomes open to discussion. But there is no room for entertaining any such question when a person's conduct affects the interests of no persons besides himself, or needs not affect them unless they like (all the persons concerned being of full age, and the ordinary amount of understanding). In all such cases, there should be perfect freedom, legal and social, to do the action and stand the consequences.” (1859, p. 303).

[21] Following this tradition, economists often reject paternalism. This holds for every and therefore also for soft paternalism. The usual justification for this position is the apparent inconsistency with the classical liberal view of the world (or the inconsistency with the tradi-

subsidies, indirect taxes are increased and/or the government cuts services and/or payments that would have benefitted these people.

18. On such an argument, see for example G. A. WiTHERS (1979).

19. On possible justifications for public subsidies for the arts, see for example B. S. FrEY and W. W. POMMEREHNE (1990). Despite his heavy criticism of libertarian paternalism, these subsidies are also defended by R. REBONATO (2012, p. 249). 
tional economic approach). ${ }^{20)}$ It is interesting to note that philosophers and professors of law are much more open-minded with respect to paternalism. This is not because they do not share liberal principles, but because they see humans as moral beings who have moral obligations not only toward others but also toward themselves. ${ }^{21)}$

[22] There is the additional question whether a consequent anti-paternalism, as proposed by some economists, makes sense at all. Labour protection laws are, for example, paternalistic measures. They are intended to force people to take precautions they would not take in the same way without these laws. An individual worker might underestimate dangers, and the employer can implement the necessary safety measures cheaper than the single employee can. This is one of the cases in which government interventions lead to higher efficiency even if there are no external effects.

[23] Finally, the question arises whether a strict anti-paternalism can really be kept up. In its final consequence, this would not only imply liberalisation of all drugs (at least for adults) and the abolition of mandatory health insurance, but also the acceptance of polygamy and slavery, as long as this happens on a voluntary basis. The statutory offense of 'non-assistance for a person in danger' is also incompatible with strict anti-paternalism. Would we really want to live in such an anti-paternalistic world? On the other hand, in a democratic society the chances of its realisation are extremely small. As the Swiss direct democracy shows, if they are able to do so, a majority of its people might vote not only for (paternalistic) social insurance systems, but also for subsidies for theatres and opera houses.

\section{On a Possible Justification of Merit Goods}

[24] Even if paternalism is omnipresent and a society without any paternalism hardly desirable, it is still open how paternalism might be justified if we stick to the classical liberal principle of normative individualism. It is true that it is hardly possible to find such a justification as long as we stay in the traditional economic model, employing a utility function with many dimensions but only one level. Here, the attempt of R. A. Musgrave (1957) fails. ${ }^{22)}$ But there are also other phenomena that are incompatible with this approach, in particular weakness of will and time inconsistence. Here, the traditional economic approach fails.

[25] This is quite different as soon as we accept that people not only have (consistent) preferences, but are also able to evaluate their own wishes and actions. Technically speaking, they have hierarchically ordered preference structures. With their upper-level (long-run) preferences, they can assess their lower-level (short-run, actual) preferences. Such a concept of human beings is relatively new (and strange) for the traditional economic approach, but it can be

20. On this, see for example T. C. LEONARD (2008), or, in German speaking countries, M. TIETZEL and C. MÜLLER (1998), as well as J. SCHNELLENBACH (2011, 2012).

21. See, for example, G. DWORKIN (2005), who speaks of „moral paternalism“, but also T. M. POPE (2004, 2005, 2005a), R. Shafer-LANDAu (2005), P. D. MARnefFe (2006), J. C. SACHA (2007), or W. GLOD (2008). - But see also R. REBOnAto (2012, 2013) who defends some kinds of medium paternalism but nevertheless criticizes libertarian paternalism because it "does not live up with its claim of being a benign, 'safe' and unobtrusive 'real-Third-Way' alternative to both paternalism and liberalism” (2013, p. 56).

22. On early discussions of merit goods see also J.G. HEAD (1966), N. ANDEL (1984) as well as K. SCHMIDT (1988). 
traced back in the philosophical tradition to ARISTOTLE who, in his Nicomachean Ethics, describes that a "distinction is set up between the rational and irrational parts of the soul; and this is what leads people to suppose that there is such a thing as injustice towards oneself, because these parts of the self may be thwarted in their respective desires, so that there may be a sort of justice between them, such as exists between ruler and subject". (1138b) ${ }^{23)}$ And H. G. FRANKFURT (1971) argues that the existence of higher-level (moral) preferences that allow a person to assess his own subordinated, actual preferences is a precondition for seeing human beings as 'persons' with a free will, because this perspective requires that they know about their will and can reflect about it. ${ }^{24)}$

[26] This model with hierarchically ordered preference functions, which has been applied, for example, to economic problems by R. H. THALER and H. M. SHEFRIN (1981) in their model with a 'planer' and a 'doer', makes it possible to understand how people bind themselves in attempts to overcome problems of weakness of will and to analyse such behaviour by applying the economic approach. ${ }^{25}$ One can establish self-bindings, however, not only individually, but also collectively: merit goods can be interpreted as a kind of collective self-binding (or self-commitment). If, for example, we see the danger that we are not provident enough to secure a decent life after retiring, we can introduce forced savings via the political process, being fully aware that by acting in accordance with our short-run preferences we would never realise the necessary savings.

[27] The possibility of collective self-binding is how G. BRENNAN and L. LOMASKY (1983) justify the existence of merit goods. They speak of higher-level preferences as 'reflective' ones, and they show that these preferences are more relevant in political processes than on markets. Decisions in elections and referenda are 'low-cost decisions'; the individuals act, as H. KLIEMT (1986) formulates it, behind a "veil of insignificance". ${ }^{26)}$ Thus, in these situations it is easier to follow the reflective preferences than on markets where the costs of violating short-run preferences appear immediately, while the costs of violating long-run preferences show up only in the future. This is the first and so far only convincing justification for paternalistic measures by the government, even if it might be impossible to justify in this way all such measures that are applied today. G. BRENNAN and L. LOMASKY (1983) also point to the fact that this concept is compatible with normative individualism. Thus, it is no longer possible to use the latter as a principle objection against merit goods (or paternalism). ${ }^{27}$

[28] Whenever such rules are decided on in democratic processes, this does not imply an interference with consumer sovereignty, because we accept them voluntarily. It is only an interference in as much as the overruled minority also has to stick to these rules. This is, how-

23. On a short history of the philosophical tradition, see also G. BRENNAN and L. LOMASKY (1983, pp. 195f.).

24. A.K. SEN (1977) argues in a similar way with a hierarchy of preferences that even includes more than two levels.

25. On this, see the classical contribution by J. Elster (1979), but also J. Elster (2000) as well as T. C. SCHELLING $(1978,1980)$.

26. On this, see also G. KIRCHGÄSSNER (1992, 2010).

27. T. GRÜNE-YANOFF (2012) denies this and claims that there is a (necessary) conflict between libertarian paternalism and liberal principles, but he does not take into account the approach of G. BRENNAN and L. LOMASKY (1983) 
ever, a property of all democratic processes, as long as we do not demand unanimity. ${ }^{28)}$ Because the opposing minority also has to accept the decision, the interference should - according to the concept of soft paternalism - be as mild as possible. ${ }^{29)}$

[29] The approach of Constitutional Economics as founded by J.M. BUCHANAN and G. TULLOCK (1962) as well as the approach used by J. RAWLS (1971) in his Theory of Justice can be understood in analogy to the model of hierarchical ordered preference functions. Here, two different decision levels are distinguished: the constitutional level (the original position) and the level of the current political process. On the first level, decisions are taken behind a 'veil of ignorance', i.e. the individuals do not know exactly how they will be affected later on (in the current political process) by the rules they have to decide on. Thus, the long-run or reflective preferences are relevant, while later on the short-run preferences dominate. At the constitutional level, the rules are fixed in accordance with which later decisions have to be taken. This analogy to the situation of collective self-binding holds at least as long as we assume that, at the constitutional level, the reflective preferences dominate. ${ }^{30}$

\section{$4 \quad$ Possible Applications of Soft Paternalism}

[30] There are quite a lot of proposals on how nudges for 'more reasonable' behaviour might be imposed. ${ }^{31)}$ There are mainly three anomalies that should be overcome or exploited: status quo bias, weakness of will and time inconsistence, the latter two often being closely associated. The most important application areas are old age pensions and the health system. With respect to the latter, problems of addictive behaviour and fighting obesity are the main topics, but questions of organ donations are also often discussed.

[31] With respect to old age pensions, one topic is to exploit the status quo bias to enrol in the 401(k) savings plans discussed above. Another proposal that intends to overrule time inconsistency goes back to an investigation by R. H. THALER and S. BENARTZI (2004). One might counteract the high short-run discount rates by offering savings contracts that become operative only in the future. One possibility is to propose a contract that fixes that a share of future income continues to increase as long as a savings rate is realised that is fixed a priori. The authors show in a case study with three companies that the savings rates of the involved employees nearly quadrupled within 40 months, from 3.5 to 13.6 per cent of their income. This happened despite the fact that they always had the possibility to opt out of the programme without any drawbacks. The authors classify offering such a programme as an example of libertarian paternalism, because participation was absolutely voluntary and the goal of raising the savings rate was realised, nevertheless.

28. Even K. WiCKSELL (1896), who - in principle - demanded unanimity for such decisions, accepted that "absolute unanimity may have to be ruled out for practical reasons" (p. 92).

29. On this, see for example A. V. AAKEN (2006).

30. On this "distinction in our thinking between the constitutional level of the discourse, evaluation, or choice and the post-constitutional level”, see also J.M. BUCHANAN (1986, p. 86).

31. On this, see for example the suggestions in R. H. THALER and C .R. SunsteIN (2008), or, with special reference to the Netherlands, P. KORMAN and H. PrAST (2010). 
[32] In the health area, among others, 'sin taxes' are discussed, i.e. taxes on alcohol, nicotine and fatty foods. If we do not refer to compensations for negative external effects caused by the consumption of such goods, such taxes can hardly be justified at all. This is obvious whenever we follow the arguments of JoHn STUART MiLL reprinted above. Moreover, they have regressive distributional consequences because - ceteris paribus and on average - lowincome people spend more money for cigarettes, alcohol and fatty foods. J. GRUBER and B. Koszegi (2004) argue, however, that such nicotine taxes might even be progressive if their revenue is used to reduce other (regressive) taxes and because low income-people react stronger to changes in the price of cigarettes. And non-smokers of all income classes profit in any case.

[33] As an alternative to today's tax regimes, T. O’DonOGHUE and M. RABIN (2003) propose a model that prohibits buying cigarettes if one has not previously bought a license to buy 2,500 cigarette packets. The price for this license should be 5,000 U.S. dollars; the cigarettes themselves should not be taxed. For addicted smokers, the financial burden would be the same as today, but the barrier to start smoking would be considerable higher and might deter many potential beginners. If we assume that at least some of the people who started smoking - following their long-run preferences - did not like to smoke at all, this system would represent a Pareto improvement compared with today, because nobody would be worse off, but at least some would be better off. ${ }^{32)}$

[34] It is obvious that this proposal would fail simply for practical reasons. It would be necessary to eliminate every intermediary trade. One might try to apply drastic penalties to make sure that only those who have a license receive cigarettes and that they do not pass these onto others. Besides the fact that this would open a new black market, it would no longer be possible to speak of soft or libertarian paternalism, given the necessary controls and penalties. Nevertheless, this model demonstrates a basic intention of the proponents of soft liberalism: whenever possible, no one's situation should be worsened by such measures. ${ }^{33)}$

[35] Obesity is increasingly a societal problem in Europe, but in particular in the United States, where the share of obese people has increased quite a lot during recent decades. ${ }^{34)} \mathrm{A}$ possibility to reduce the consumption of fatty foods might be to arrange food products in supermarkets in such a way that low-calorie foods are easily accessed, but high-calorie foods less accessible. This is especially important for foods primarily attractive for children. From the marketing literature, we know that the arrangement of products in a store or supermarket has an impact on sales. ${ }^{35)}$ This opens a possibility to exert influence. It is open, however, whether the owners of these shops are ready to do this: they might arrange their goods so as to maximise their profits. ${ }^{36)}$ If the government prescribes such an arrangement, it is hardly pos-

32. On optimal sin taxes that relate, however, to the consumption of potato chips, see T. O'DONOGHUE and M. RABIN (2006).

33. On the possibilities of soft paternalism to reduce smoking, see also G. LUCAS (2012).

34. On this, see D. Cutler, A. Deaton and J. M. Shapiro (2003) for the United States and G. BrunELlo, P.C. Michaud and A. SANZ-DE-GALDEANO (2009) for Europe.

35. See, for example, X. DrÈze, S. J. Hoch and M. E. PURK (1994) or P. CHANDON et al. (2009).

36. Investigating supermarkets in Melbourne, H. DiXON, M. SCULLY and K. PARKINSON (2006) show that highenergy food is often placed close to cash points; this is to induce children to ask their parents to buy these 
sible to speak of 'soft' paternalism, leaving aside the fact that this would create a huge control problem. Similar results but without such objections could be reached by the assignment of food in this way in public cafeterias. ${ }^{37)}$ However, the problem of obese children, very important (not only) in the United States, could not be tackled in this way. Taking all available evidence together, the experiments performed so far do not justify any hope for big successes in this area, but the strong paternalistic measures tried so far have not worked any better. ${ }^{38)}$

[36] One area where soft paternalism is much more effective than in the examples discussed above but might cause severe ethical problems is organ donation. ${ }^{39)}$ It is again the status quo that matters. Up to 2012, Germany had the consent rule: it allowed a doctor to extract an organ from a dead person if and only if this person declared his willingness to donate an organ during his life (for example by filling in a corresponding document ('pass')) or if the relatives consented to this. Because this consent is necessary within a very short period of time, these relatives are exposed to a highly problematic decision situation. The result is that in Germany only relatively few organs were available and about 1,000 persons died every year while waiting in vain for an organ. ${ }^{40)}$

[37] In contrast to this, in Austria the objection rule holds: anyone who does not explicitly object is a possible organ donator after his death. This solution, however, also poses problems, because the extraction of an organ implies an invasion into the integrity of a human person even if this person is already dead. According to our (today) prevailing moral convictions, such an invasion - absent the consent of the person involved - should only be allowed under very restrictive conditions. Whether the fact that the life of another human person can be prolonged is sufficient for this is contested. Nevertheless, this principle allows about 50 percent more transplantations to be performed in Austria than would otherwise be possible. ${ }^{41)}$ As some scientific investigations also show, applying the rule in a country does have a significant impact on the number of possible transplantations. But they also show that this is not the only impact factor. $^{42)}$

[38] According to the new German regulation that has been in effect since 2012, German citizens are regularly asked by their health insurance companies whether they would accept

for them. On the other hand, R. JUST and C.R. PAYNE (2009) believe that there are possibilities to have such an impact on consumers without reducing the profits.

37. On this, see for example J. S. DownS, G. LOEWENSTEIN and J. WISDOM (2009) as well as J. WiSDOM, J.S. DOWNS AND G. LOEWENSTEIN (2010).

38. On this, see for example G. Loewenstein, T. BrennAn and K. G. Volpp (2007), D. R. Just and C. R. PAYNE (2009) as well as M. M. GALIZI (2012). For experiences in the United Kingdom, see A. BuRGESS (2012).

39. On this, see for example R. H. THALER and C. R. SUNSTEIN (2008, pp. 240ff.). - On the ethical problems of nudging, see also L. BOVENS (2009).

40. See: Bundestag beschliesst Organspendereform, ZEIT-ONLINE of 25 May 2012, http://www.zeit.de/politik/deutschland/2012-05/organspende-bundestag (27/06/12).

41. On this, see EUROTRANSPLANT (2011, p. 36). - However, this is true only of those transplantations that are operated via Eurotransplant. Those transplantations that are carried out in the same hospital as where the removal took place are not covered by this statistic. There is, however, no obvious reason that this should largely bias the results.

42. On this, see for example A. ABADIE and S. GAY (2006) or A. RhitAliA et al. (2009). 
donating an organ when they die. This is also a consent rule, but in contrast to the former one, there are now strong incentives for the individuals to be aware of this problem. The 'nudge' is here much weaker than with the objection rule. It corresponds more to the philosophy of soft paternalism, because those involved are directly confronted with the relevant information and it cannot happen that somebody who never thought of this problem becomes an organ donator against his will. Even if this nudge is relatively soft, an increase of the willingness to donate organs is expected. We have to wait and see whether this will be the case. ${ }^{43)}$

[39] In recent years, quite a lot of possibilities to apply measures of soft paternalism have been presented. Some of these proposals can be realised, and there are certainly others that are possible and might be effective. One should, however, not have exaggerated expectations. What we know about health measures, in particular, demands reservations. But even with respect to the $409(\mathrm{k})$ plans for old age pensions, the differences are not as dramatic as it might appear at a first glance. After about three years, the gap between those automatically and those not-automatically enrolled is nearly closed, but the former have nevertheless saved more for their retirement period. And the example of organ donations shows that such measures might also cause considerable ethical problems.

\section{On the Critique of Soft Paternalism}

[40] It is obvious that the concept of soft paternalism also provoked some criticism. Even if some objections are definitely justified, the fierceness of many of these critiques is somewhat astonishing. This might relate to the claim that soft paternalism - unlike traditional paternalism - does not interfere with the preferences of the individuals but respects them and only helps them to decide in accordance with their 'true' preferences.

[41] J. SCHNELlENBACH (2012) questions the (welfare-economic) foundation of soft paternalism. He argues that it is open whether the proposed measures increase efficiency, because the government does not have the all-embracing knowledge that would be necessary to guarantee a Pareto improvement (pp. 268ff.). Moreover, the autonomy of individuals is reduced, which is a necessary component of their individual well-being. This might lead to incalculable, unintended side effects. Because the measures necessarily imply redistribution, minorities might be negatively affected by an undesired distribution policy. According to H. BECK (2010, p. 53), dismay may also arise because a 'psychological tax' might be imposed on people with different preferences, for example, smokers by governmental measures like antismoking education campaigns.

[42] G. WhitMAn (2006) accuses the proponents of soft paternalism of being, with their approach, in the same situation as the theory of externalities was before 1960, i.e. before RONALD COASE showed in his famous paper the possibility of internalisation of external effects by negotiations. They would privilege some private interests at the expense of others, they would neglect the possibility of negotiations within a person between the self with short-

43. Due to a big scandal in 2012, the number of transplantations drastically decreased in 2013. Thus, at the moment it is impossible to say whether the new rule will finally increase the number of donations. See: Zahl der Organspender sinkt auf neuen Tiefpunkt, Zeit-Online of January 15, 2014, http://www.zeit.de/gesellschaft/2014-01/organspende-dso-transplantation-zahlen (05/02/14). 
run and the self with long-run preferences and also the possibility to develop one's own procedures to overcome time inconsistency, and they would not take into account the possibility of government failure.

[43] Soft paternalism is also accused of impairing the learning of individuals. J. SCHNELLENBACH (2012), for example, criticises that soft paternalism reduces the incentives for the individual to learn by trial and error. ${ }^{44)}$ E. L. GLAESER (2006) argues that libertarian paternalism reduces the incentives for the individuals to do something against weakness of will. Thus, the existence of decision anomalies might rather be an argument for further restrictions than for extensions of governmental activity. J. SCHNELLENBACH (2011) notices in this context that there is a market for self-bindings. Whenever one wants to bind oneself, this is possible via this market, and these self-bindings are generally more unerring and more welfare-improving that collective ones. He accepts collective self-bindings at the utmost for real addictive behaviour.

[44] J. SChNELLENBACH (2012) also questions that the higher-order, long-run preferences really are the 'true' preferences that should be relevant for the behaviour of individuals, because individuals are more aware of the consequences of following their actual preferences, while the long-run preferences are more 'expressive'. A similar argument is used by E.L. GLAESER (2006) when he states that individuals have fewer incentives to decide 'correctly' in politics than on markets. ${ }^{45)}$ J. SCHNELLENBACH (2012a) also questions whether one should really follow the long-run preferences, because how long somebody will remain alive is open.

[45] R. SugDEN (2008) criticizes that it is open how and by whom the proposals of soft paternalism might be implemented; they hardly discuss this question and seem to assume that in a democratic society this does not cause a major problem. ${ }^{46)}$ Several critiques suppose that these proposals are addressed to an omniscient planner or presuppose a benevolent dictator. This not only implies an arrogance of knowledge as already criticised by F. A. V. HAYEK $(1945),{ }^{47)}$ but also presupposes that this planner is not subject to the same behavioural anomalies as the 'normal' individuals who are to be influenced by the nudges imposed by the planner. ${ }^{48)}$ Soft paternalism offers in addition, as H. BECK (2010) mentions, gateways for malpractice and manipulation. On the other hand, E. SELiger and K. P. Whyte (2012) insinuate that these soft nudges are hardly suited to solve complex political problems. But then even libertarian paternalism has to shift to 'harder' measures; it is no longer soft. Generally, there is the danger that - starting with soft measures - we come on a slippery slope and end with 'hard' paternalism. ${ }^{49)}$

44. B. I. CARLIN, S. GERVAIS and G. MANSO (2013), use similar arguments. In contrast to J. SCHNELLENBACH (2011, 2012), however, they have no fundamental objections to soft paternalism.

45. This argument goes back to J. M. BuCHANAN (1954).

46. See also R. REBOnAto (2012, p. 11; pp. 221ff.).

47. See, for example, M. J. Rizzo and G. Whiteman (2009, p. 910).

48. See for example G. WhitemAn and M. J. Rizzo (2007, pp. 442f.) as well as M. J. Rizzo and G. WhitemAN (2009a, pp. 723ff.).

49. On this, see for example M. J. Rizzo and G. Whiteman (2009a) as well as G. Whiteman and M. J. Rizzo (2007.) 
[46] Some of these objections are definitely justified. Some of the expectations connected with measures of soft paternalism are largely exaggerated. This is shown, not least, by the experience with such measures in the health system. Moreover, the fact that we can observe behavioural anomalies does not imply that the government must intervene. However, none of the proponents of soft paternalism demands this. On the other hand, there exists today not only a soft but a rather hard paternalism, using not only taxes and subsidies but also prescriptions and prohibitions. The concept of soft paternalism should not be compared with a situation without any paternalism, which some people might consider ideal. Otherwise we start a discussion in Nirvana, a situation that existed in (traditional) neoclassical economics ${ }^{50}$ ) but that modern institutional economics has rightly abandoned. The crucial question (or the intention of the proponents of libertarian paternalism) is rather how existing paternalistic regulations could be shaped to be 'softer' than today, i.e. with lesser (or less strict) interventions into the individuals' decisions. The hope to be able to substitute all hard paternalistic measures with soft ones might, however, be an illusion. The best we can hope is to substitute some of the hard by softer measures.

[47] Other critiques are largely overstated. This holds for large parts of the (missing) welfare-economic foundation. As shown above, the model of hierarchically ordered preference functions provides such a foundation. Even if there are possibilities for individual selfbindings in some areas, this does not imply that collective self-bindings via the political process are not admissible. One cannot prohibit this the citizens in a democratic system. In such systems, the citizens, not a super-ordinated authority, decide on such questions, be it themselves (in direct democracy) or via their representatives (in the indirect system). The problem is hardly, as E.L. GLAESER (2006) believes, that the individuals are less responsible with political than with market decisions. There is evidence that by making political decisions, they are more other-regarding than on markets. ${ }^{51)}$

[48] Remarkable in this respect are also the comments of J. SCHNELLENBACH (2012, p. 274) who enjoins voters that "the key for electoral success of paternalistic policies ... is not a true material self-interest of voters", and he criticises the political process because "paternalistic policies ... can be supported by majority voting, even if this is not in the material self-interest of a majority of voters". And, without presenting any empirical evidence, he claims, "Democratic politics is subject to its very own behavioural biases, and they tend toward increasing the magnitude of pre-existing cognitive biases.” Thus, he reinforces the prejudice, in most cases no longer held by modern economics, that the economic approach takes into account only material values, that everything else does not count, and that, moreover, narrowly understood self-interest should be the only criterion for rational individuals. A necessary condition for the well-functioning of a modern democratic society, however, is that, in some situations, a majority of citizens do not follow their own narrow self-interest, but support regulations that are important for the stability of this society. ${ }^{52)}$ His analysis is blind to this fact. Moreover,

50. See for example the critique of model Platonism by H. AlberT (1963.)

51. On this, see G. KirchgäsSner (2010) as well as W. W. Pommerehne and F. Schneider (1985), who showed for the canton Basel-County that, in referenda about the first column of the Swiss old age pension system (AHV), a majority of voters voted in favour of those with low income and against their own material interests.

52. On this, see G. KIRCHGÄSSNER (2008, pp. 154ff.). 
when individuals realise that their remaining lifetime is rather limited, for example due to a fatal illness, they often regret that they too often followed their short-run preferences and thus missed chances that will never come back.

[49] The proposition that the short-run rather than the long-run preferences are the individuals' true ones is also hardly convincing. Given the laboratory and field results, this argument is compatible only with a very high discount rate. Under this assumption, as G. S. BECKER and K. M. MurPhy (1988) have demonstrated, even extreme addictive behaviour can be interpreted as resulting from the rational decisions of an autonomous, mature individual. Given that we cannot objectively measure the 'true' preferences, we can of course neither prove that the short-run nor that the long-run more closely correspond to the true preferences. The fact that human persons, reflecting on themselves, usually take on the long-run perspective rather provides evidence for the long-run preferences, as does the fact that individuals often heavily underestimate the costs of the actions that are guided by their short-run preferences. Otherwise it is difficult to understand why people regret their own earlier behaviour when foreseeable consequences become obvious that were not taken into account before. ${ }^{53)}$

[50] The critique of J. SCHNELLENBACH (2012) that it is never certain that measures of libertarian paternalism lead to a situation closer to a society's utility frontier is also hardly convincing. It is correct that there is hardly any economic policy measure that produces only winners and no losers and that therefore can guarantee to lead to a Pareto improvement. From this perspective, at most a minimal state in the sense of F. A. v. HAYEK (1960) or R. NOZICK (1974) might be justified, even if the foundations for it are strongly contested. But the question is not whether we can guarantee a Pareto improvement. This would be possible only in a - non-existent - world of perfect foresight. If we intend to use the Pareto criterion at all, it is relevant whether we can expect a Pareto improvement. For this, we do not need perfect foresight, but only that individuals form expectations and, whenever there is new information, are able to adjust these expectations, i.e. that they are able to learn. ${ }^{54)}$

[51] The problem with democratic decisions over paternalistic measures is, of course, that a majority decides. Thus, nearly always some part of the population that does not support this decision has, nerveless, to pay for it. Ideally, at the constitutional level, i.e. behind a veil of ignorance, it should be decided in which areas such decisions should be made and how far they are allowed to reach. One can only speculate which rules would be decided on in such a situation as done, for example, in the constitutional theories of J. M. BUCHANAN and G. TUlLOCK (1962), J. RAWLs (1971) or J. M. BuCHANAN (1975). The problem is, of course, that

53. It is not the trivial regret at not having been lucky when making a risky decision (investment), that is relevant in this respect, but the consciousness that I should have behaved differently even if I have been lucky and my behaviour did not have negative consequences for me.

54. If one accepts that the government should take on measures only that lead to a Pareto improvement, then it would also be illegitimate to provide information in order to overcome informational asymmetries or to financially support institutions that provide such information, for example, such as the Stiftung Warentest in Germany. The costs for such activities have to be borne by the taxpayers. Thus, there are citizen who have to pay for these activities but do not benefit. They come into a worse position, which violates the Pareto criterion. On this, see also P. D. MARnEFFE (2006) who believes that it does not make sense with respect to governmental actions always to look for justifications with non-paternalistic arguments, because this sometimes excludes the best arguments for such measures. 
we can establish such a situation in most cases, if at all, at best partially. ${ }^{55)}$ But this does not provide anybody the right to authoritative define which decisions the citizens are allowed to make collectively via the political process and which decisions have to be made by markets. This is a political decision which is to be made by the citizens in democratic processes and not a decision of scientists (economists) even if they believe to be guided by liberal principals. Whoever believes that he has the right to prescribing this is subject to the same blame, i.e. to try to impose the own value system on others, which is sometimes made against proponents of libertarian paternalism. ${ }^{56)}$

[52] It is also interesting to note that that libertarian paternalism might have a tendency to stabilise the status quo. The corresponding argument of J. SchnELLENBACH (2012) is that such measures are oriented toward prevailing social norms and that this strengthens their social acceptance. The fact is, however, that libertarian paternalists intend to change the status quo in relevant societal areas, such as the health and the old age pension system. This accusation is insofar curious, even if it cannot be denied that they intend to help some normative ideas about, for example, healthy foods or reasonable retirement provisions, to gain acceptance in society.

[53] To stabilise the status quo is, on the other hand, not necessarily bad. We believe it to be so important in some areas of policy that we secure it in the constitution by demanding qualified majorities for changes. But the status quo is also highly relevant in normative economics. ${ }^{57)}$ It normally works with the most conservative of all welfare criteria, the Pareto criterion. In his critique of soft paternalism, J. SCHNELLENBACH (2012) also refers to this criterion and therefore defends, at least implicitly, the status quo. Insofar, his corresponding critique of soft paternalism is remarkable.

[54] The argument by E. L. GLAESER (2006), that soft nudges reduce the incentives to learn, is also ambivalent. This might be so in particular cases, but does not mean anything. The existence of behavioural anomalies demonstrates that individual learning is not sufficient to avoid these. Even if the individuals recognise their 'errors' and the negative consequences of 'wrong' behaviour, this does not imply that next time they will not again be subject to such an anomaly. In particular, if they have realised that such an anomaly is effective, they might approve giving such nudges that help avoid the negative consequences. Moreover, quite generally, when it makes sense to learn by oneself and when we should learn from the experiences of others very much depends on the concrete situation. Learning by trial and error is not always better, as J. SCHNELLENBACH (2012) suggests.

\section{$6 \quad$ Summary and Concluding Remarks}

[55] Political interventions into market processes are usually justified by the existence of external effects and/or public goods. Here, rights and interests of third parties are crucial. The

55. On this, see G. KIRCHGÄSSNER (1994).

56. See, for example, J. SCHNELLENBACH (2011, p. 452).

57. On this, see the contributions in Constitutional Political Economy 15 (2004), issue 2, in particular the introduction by G. BRENNAN (2004). 
goal is to compensate positive as well as negative effects of (legitimate) individual actions on uninvolved third parties. In contrast to this, the rights and interests of third parties are not at the core of paternalistic measures. The objective is to help citizens to make decisions that are in their own best interests. In public economics, since R. A. MusGrave (1957), the term 'merit goods' is often used for such measures.

[56] To influence individuals contrary to their own preferences is - at least at a first glance in contradiction to the traditional vision of normative individualism. According to this concept, the values of the autonomous individuals are the only ones that should be relevant in society, and nobody has the right to prescribe to others which values to accept. This concept is also behind (traditional) normative economics, i.e. welfare economics, and it is concretised in the concept of consumer sovereignty. However, paternalism does not have to be seen in contradiction to this normative concept as soon as, following the philosophical tradition, we accept that human persons are able to reflect their own behaviour. This implies that they possess hierarchically ordered preference functions; they are able to evaluate their short-run preferences with their super-ordinated reflexive (long-run) preferences. Paternalistic political measures can be understood as collective self-bindings via the political process. Even if it is impossible to justify all paternalistic measures that are installed today, a general rejection of every paternalism due to its incompatibility with liberal principles is no longer possible.

[57] While traditional, 'hard' paternalism uses prescriptions and prohibitions, as well as strong incentives like taxes and subsidies, soft or libertarian paternalism tries to avoid such direct measures and to employ only 'soft' measures: nudges. The foundation for such measures are results of behavioural economics that show that people behave quite differently, despite identical objective information, depending on how information is presented ('framing') what the default option (status quo) is. The main method of soft paternalism is to present the available information in such a way as to help individuals to make their decision in their own (long-run) interest. This concept is called 'libertarian' insofar as it intends to influence the individuals' decisions in a particular direction without restricting their decision leeway.

[58] A whole series of policy measures have been proposed within this framework. They relate mainly to retirement provisions and to the health system; among the latter manly problems of obesity, smoking, and organ donations are tackled. The measures proposed often present a particular alternative as status quo that a particular point of view evaluates as being preferable. There is no problem to deviate from this default solution, but it demands an active decision.

[59] With a more precise view of these measures, , however, two aspects become obvious. First, even if they are at all feasible, some of them are not really effective. This holds in particular for measures related to health. Second, they can substitute at best for a small part of those 'hard' paternalistic measures that are installed today. Moreover, the transition between traditional and soft paternalism is fluid; at least some of the proposed measures imply relative price changes. This becomes obvious, for example, as soon as 'sin taxes' are discussed. Thus, there is only a gradual difference between soft and hard paternalism, and all arguments against the latter can also be brought forward against the former. 
[60] Some (fundamentalist economic) critics of soft paternalism insinuate an (in their opinion) ideal world without any paternalism. This holds in particular for those passages where it is argued that realisations of the proposals of soft paternalism would worsen the situation. Actually, however, we are living in a world in which paternalism is omnipresent, independent of whether we consider mandatory social insurance, subsidies for operas and theatres or preventive medical check-ups free of charge. What the effects of soft paternalistic measures really would be can be evaluated only by comparison with today's real situation. Here, the main question is which hard paternalistic measures could be substituted with softer ones.

[61] A radical anti-paternalism, as might be traced back to JoHn STUART MiLL and as is proposed by some economists, would hardly make sense. It would, for example, imply the abolition of (nearly) all labour safety laws. Moreover, it can - presumably - not be realised. This holds at least for democratic political systems, and it becomes quite obvious in the Swiss democratic system, where many merit goods are politically legitimised by referenda.

[62] There is also another reason why radical anti-paternalism is hardly possible. As soon as it is realised that the way information is presented influences the individuals' decisions, the question how information should be presented has to be answered. Whenever the default option has an impact, the government or the respective firm influences the citizens (or employees) by providing the 'normal' situation. The same holds whenever behaviour depends on the frame used. In these situations, one should consider which frame to choose or which default option should be proposed. Closing one's eyes to this fact and just continuing what has been done before might hardly be a rational strategy. Moreover, in these situations the argument, dubious also for other reasons, does not hold that the short-run should have more weight than the long-run preferences. Depending on the default options, the individuals seem to have different short-run preference functions (or the same short-run preference function leads to different results depending on the default option). Thus, referring only to the short-run preferences does not make it possible to say which solution is 'better' and which one is 'worse'. The short-run preference function does not imply criteria for this decision. On the other hand, whenever such a conflict exists between short-run preference functions (or between actions suggested by different frames given the same short-run preference function) it makes sense to refer to the long-run preferences.

[63] That critics of soft paternalism refer to F. A. V. HAYEK might not be an accident; he is an extreme critic of government interventions, in particular of governmental paternalism. However, when criticising paternalism, it is often not taken into account that, in democratic systems, decisions about introducing such measures are not taken by a central planner, but (in the direct democratic system) by the citizens themselves or (in the representative system) by their representatives. In order to be re-elected, the latter base their decision at least partly on the preferences of the citizens. If one accepts the democratic principle, the question is whether the citizens approve a policy and not whether it is compatible with a particular ideology. The latter might be an argument in the public discussion, but if a majority of citizens demands the introduction of mechanisms for collective self-binding, this cannot be prohibited in a democracy. Constitutional economics might indicate which results are to be expected given particu- 
lar rules. In a democratic system, however, deciding which rules are to be followed is the task of the citizens themselves (or their representatives). ${ }^{58)}$

[64] In contrast to other critics, J. SchnellenBACH (2011, 2012) acknowledges that such decisions are based on a democratic political process, but he criticizes, as mentioned above, that the voters or citizens do not follow their "true material interests" (2012, p. 274). This critique lies in the tradition of F.A. V. HAYEK, who was extremely critical of democratic processes; he confessed, "to preferring non-democratic government under the law to unlimited (and therefore essentially lawless) democratic government”. (1979, p. 35). B. CAPLAN (2007) is also in this tradition. According to him, "democracy fails because it does what voters want" (p. 39). J. SCHNELLENBACH (2012) seems attached to this opinion. It is, however, debatable whether it would really be an advantage to no longer decide for ourselves about the organisation of political processes and instead to allocate this task to the benevolent dictators of Constitutional Economics who insinuate that all others (only) maximise their own utility, while they themselves intend to maximise social welfare. Compared to this pretension, soft paternalism's is rather moderate, even if it can (and should) be rightly criticised.

58. On this, see also K. SсHмIDT (1988). 


\section{References}

AAKen, A. VAn (2006), Begrenzte Rationalität und Paternalismusgefahr: Das Prinzip des schonendsten Paternalismus, in: K. SeElmanN, A. ANDERHEIDEN, P. BÜRKLI, M. HEINIG and S. KIRSTE (eds.), Paternalismus und Recht, Mohr Siebeck, Tübingen, pp. 109 - 144.

ABADIE, A., and S. GAY (2006), The Impact of Presumed Consent Legislation on Cadaveric Donation: A Cross-Country Study, Journal of Health Economics 25, pp. 599 - 620.

AlBert, H. (1963a), Modell-Platonismus: Der neoklassische Stil des ökonomischen Denkens in kritischer Beleuchtung, in: F. KARRENBERG and H. AlBERT (eds.), Sozialwissenschaft und Gesellschaftsgestaltung, Festschrift für Gerhard Weisser, Duncker und Humblot, Berlin 1963, pp. 45 76; reprinted in: H. ALBERT Marktsoziologie und Entscheidungslogik, Luchterhand, Neuwied/ Berlin 1967, pp. 331 - 367.

ANDEL, N. (1984), Zum Konzept der meritorischen Güter, Finanzarchiv 42 (1984), pp. 630 - 648.

ARISTOTELES, Nicomachean Ethics; English translation: http://www.virtuescience.com/nicomacheanethics.html.

ARNESON, R.J. (2005), Joel Feinberg and the Justification of Hard Paternalism, Legal Theory 11, pp. $259-284$.

BECK, H. (2010), Ist paretianischer Liberalismus doch möglich? Verhaltenswissenschaftliche Ökonomik und Liberaler Paternalismus, List Forum für Wirtschafts- und Finanzpolitik 36, pp. 43 - 58.

BeCKer, G. S., and K. M. MurPhy (1988), A Theory of Rational Addiction, Journal of Political Economy 96, pp. $675-700$.

Bernheim, B. D., A. FradKIn and I. PoPOV (2011), The Welfare Economics of Default Option: A Theoretical and Empirical Analysis of 401(k) Plans, NBER Working Paper Nr. 17587, November.

Bovens (2009), L., The Ethics of Nudge, in: T. GRÜNE-YANOFF and S. O. HANSEN (eds.), Preference Change: Approaches from Philosophy, Economics and Psychology, Springer, Dordrecht et al., pp. $207-219$.

Brennan, G. (2004), An Introduction to the Status Quo, Constitutional Political Economy 15, pp. 172 $-132$.

BRENNAN, G., and L. LOMASKY (1983), Institutional Aspects of Merit Goods Analysis, Finanzarchiv N.F. 41, pp. $183-206$.

Brunello, G., P.-C. Michaud and A. SANZ-DE-GaldeAno (2009), The Rise of Obesity, Economic Policy 24, pp. 551 - 596.

Buchanan, J. M. (1954), Individual Choice in Voting and the Market, Journal of Political Economy 62, pp. $334-343$.

BuCHANAN, J. M. (1975), The Limits of Liberty, University of Chicago Press, Chicago.

Buchanan, J. M. (1986), Kommentar, in: P. KoslowsKi, Ethik des Kapitalismus, Mohr (Siebeck), Tübingen, $6^{\text {th }}$ edition 1998 , pp. $81-92$.

BuChanAN, J. M., and G. TullOCK (1962), The Calculus of Consent: Logical Foundations of Constitutional Democracy, University of Michigan Press, Ann Arbor 1962.

Burgess, A. (2012), 'Nudging' Healthy Lifestyles: The UK Experiments with the Behavioural Alternative to Regulation and the Market, European Journal of Risk Regulation 1/2012, pp. 3 - 16.

CAMERER, C. F., S. IsSACHAROFF, G. LOEWEnStein, T. O’DONOGHUE and M. RABin (2003), Regulation for Conservatives: Behavioral Economics and the Case for 'Asymmetric Paternalism', University of Pennsylvania Law Review 151, pp. 1211 - 1254.

Caplan, B. (2007), The Myth of the Rational Voter: Why Democracies Choose Bad Policies, Princeton University Press, Princeton N.J.

CARLIN, B. I., S. Gervais and G. MANSo (2013), Libertarian Paternalism, Information Production, and Financial Decision Making, Review of Financial Studies 26, pp. $2204-2228$. 
Chandon, P., J. W. Hutchinson, E. T. BRAdlOW and S. H. Young (2009), Does In-Store Marketing Work? Effects of the Number and Position of Shelf Facing on Brand Attention and Evaluation at the Point of Purchase, Journal of Marketing 73, pp. 1 - 17.

ChOI, J. J., D. LAiBson, B. MAdRian and A. Metrick (2003), For Better or For Worse: Default Effect and 401(k) Savings Behavior, in: D. WISE (ed.), Perspectives in the Economics of Aging, University of Chicago Press, Chicago, pp. 81 - 121.

CHOI, J. J., D. LAIBSOn, B. MADRIAN and A. METRICK (2003a), Optimal Defaults, American Economic Review 93, pp. 180 - 185.

COASE, R. H. (1960), The Problem of Social Cost, Journal of Law and Economics 3 (1960), pp. 1 44.

Cutler, D., A. Deaton and J. M. Shapiro (2003), Why Have Americans Become More Obese, Journal of Economic Perspectives 13.3, pp. $93-118$.

DiXon, H., M. Scully and K. PARKinson (2006), Pester Power: Snackfoods Displayed at Supermarket Checkouts in Melbourne, Australia, Health Promotion Journal of Australia 17, pp. 124 - 127.

Downs, J. S., G. LOEWENSTEIN and J. WiSDOM (2009), Strategies for Promoting Healthier Food Choices, American Economic Review (Papers and Proceedings) 99.2, pp. 159 - 164.

DrÈZE, X., S. J. HOCH and M. E. PURK (1994), Shelf Management and Space Elasticity, 70, pp. 301 326.

DwORKIN, G. (2005), Moral Paternalism, Law and Philosophy 24, pp. 305 - 319.

ElSTER, J. (1979), Ulysses and the Sirens, Studies in Rationality and Irrationality, Cambridge University Press, Cambridge.

ELSTER, J. (2000), Ulysses Unbound, Cambridge University Press, Cambridge.

EUROTRANSPLANT INTERNATIONAL FOUNDATION (2011), Annual Report 2011, Leiden.

FEINBERG, J. (1986), The Moral Limits of the Criminal Law Volume 3: Harm to Self, Oxford University Press, Oxford.

Frankfurt, H. G. (1971), Freedom of the Will and the Concept of a Person, Journal of Philosophy 68, pp. $5-20$.

Frey, B. S., and W. W. Pommerehne (1990), Public Promotion of the Arts: A Survey of Means, Journal of Cultural Economics 14, pp. 73 - 95.

GaLizI, M. M. (2012), Label, Nudge or Tax? A Review of Health Policies for Risky Behaviours, Journal of Public Health Research 1:e5, pp. $14-21$.

GinsBuRG, T., J. S. MAsUR and R. H. McAdAMs (2013). Libertarian Paternalism, Path Dependence, and Temporary Law, University of Chicago, Public Law and Legal Theory Working Paper No. 431, June.

Glaeser, E. L. (2006), Paternalism and Psychology, University of Chicago Law Review 73, pp. 133156.

GLOD, W. (2008), How Not to Argue Against Paternalism, Reason Papers 30, pp. 7 - 22.

Gruber, J. and B. Koszegi (2004), Tax Incidence When Individuals are Time-Inconsistent: The Case of Cigarette Excise Taxation, Journal of Public Economics 88, pp. 1959 - 1987.

GRÜNE-YANOFF, T. (2012), Old Wine in New Casks: Libertarian Paternalism Still Violates Liberal Principle, Social Choice and Welfare 38, pp. 635 - 645.

HAYEK, F.A. V. (1945), The Use of Knowledge in Society, American Economic Review 35, pp. 519 530.

HAYEK, F.A. V. (1960), The Constitution of Liberty, Routledge and Kegan Paul, London 1960.

HAYeK, F.A. V. (1979), Whither Democracy, in: F.A. v. HAYEK, Social Justice, Socialism and Democracy: Three Australian Lectures, Centre for Independent Studies, Sydney, pp. 33 - 45.

HEAD, J. G. (1966), On Merit Goods, Finanzarchiv NF. 25, pp. 1 - 29. 
JOLLS, C., and C. R. SunSTEIN (2006), Debiasing Through Law, Journal of Legal Studies 35, pp. 199 $-241$.

Just, D. R., and C. R. PAYne (2009), Obesity: Can Behavioral Economics Help?, Annals of Behavioral Medicine 38 (Supplement), pp. 47 - 55.

KIRCHGÄSSNER, G. (1992), Towards a Theory of Low-Cost Decisions, European Journal of Political Economy 8, pp. $305-320$.

KIRCHGÄsSNER, G. (1994), Constitutional Economics and Its Relevance for the Evolution of Rules, Kyklos 47, pp. $321-339$.

KIRCHGÄssner, G. (2008), Homo Oeconomicus: The Economic Model of Behaviour and Its Applications to Economics and Other Social Sciences, Springer, New York.

KIRChGÄssner, G. (2010), On Minimal Morals, European Journal of Political Economy 26 (2010), pp. $330-339$.

KIRCHGÄSSNER, G. (2013), Sanfter Paternalismus, meritorische Güter und der normative Individualismus, in: M. HELD, G. KUBON-GILKE and R. STURN (eds.), Grenzen der Konsumentensouveränität, Jahrbuch normative und institutionelle Grundlagen der Ökonomik, Vol. 12, Metropolis, Marburg, pp. $41-62$.

KLIEMT, H. (1986), The Veil of Insignificance, European Journal of Political Economy 2, pp. 333 344.

KocH, F. (2000), Der Aufbruch der Pädagogik, Europäische Verlagsanstalt, Hamburg.

Korman, P., and H. Prast (2010), What Does Behavioral Economics Mean for Policy? Challenges for Savings and Health Policies in the Netherlands, De Economist 158, pp. $101-122$.

Laibson, D., A. Repetto and J. B. Tobacman (2007), Estimating Discount Functions with Consumption over the Lifecycle, NBER Working Paper Nr. 13314, August.

LEONARD, T. C. (2008), Review of R. H. THALER and C. R. SUNSTEIN (2008), Constitutional Political Economy 19, pp. 356 - 360.

LOEWENSTEIN, G., and E. HAisley (2008), The Economist as Therapist: Methodological Ramifications of 'Light Paternalism', in: A. CAPLIN and A. SCHOTTER (eds.), The Foundations of Positive and Normative Economics, Oxford University Press, Oxford et al., pp. 210 - 245.

LOEWEnstein, G., T. BrenNAN and K. G. VolPP (2007), Asymmetric Paternalism to Improve Health Behaviors, Journal of the American Medical Association 298, pp. 2415 - 2417.

LUCAS, G. (2012), Saving Smokers from Themselves: The Paternalistic Use of Cigarette Taxes, University of Cincinnati Law Review 80, pp. 1 - 55.

MAdRIAN, B. C., and D. F. SHEA (2001), The Power of Suggestion: Inertia in 401(k) Participation and Savings Behavior, Quarterly Journal of Economics 66, pp. 1149 - 1187.

MarnefFe, P. D. (2006), Avoiding Paternalism, Philosophy and Public Affairs 34, pp. 68 - 94.

MiLl, J. S. (1859), On Liberty, J. W. Parker, London 1859, cited from: M. J. ADLER (ed.), Great Books of the World, Vol. 40: American State Papers, The Federalist, J.S. Mill, Encyclopaedia Britannica, Chicago et al. 1994, pp. 267 - 323.

Mors, A. (1986), Die Entwicklung der Schulpflicht in Deutschland, Dissertation, Universität Tübingen.

Musgrave, R. A. (1957), A Multiple Theory of Budget Determination, Finanzarchiv NF 24, pp. 333 $-343$.

NozICK, R. (1974), Anarchy, State, and Utopia, Basil Blackwell, Oxford.

O’Donoghue, T., and M. Rabin (2003), Studying Optimal Paternalism, Illustrated by a Model of Sin Taxes, American Economic Review (Papers and Proceedings) 93.2, pp. 186 - 191.

O’Donoghue, T., and M. Rabin (2006), Optimal Sin Taxes, Journal of Public Economics 90, pp. $1825-1849$. 
PommereHne, W. W. (1975), Budgetäre Umverteilung in der Demokratie: Ein empirischer Test alternativer Hypothesen, Zeitschrift für Wirtschafts- und Sozialwissenschaften 95, pp. 327 - 364.

POMMEREHNE, W. W., and F. SCHNEIDER (1985), Politisch-ökonomische Überprüfung des Kaufkraftinzidenzkonzepts: Eine Analyse der AHV-Abstimmungen von 1972 und 1978, in: E. A. BRUGGER and R. L. FREY (eds.), Sektoralpolitik versus Regionalpolitik, Rüegger, Gruesch, pp. 75 - 100.

Pope, T. M. (2004), Counting the Dragon's Teeth and Claws: The Definition of Hard Paternalism, Georgia State University Law Review 20, pp. 659 - 722.

Pope, T. M. (2005), Is Public Health Paternalism Really Never Justified?, Oklahoma City University Law Review 30, pp. 121 - 207.

POPE, T.M. (2005a), Monstrous Impersonation: A Critique of Consent-Based Justifications for Hard Paternalism, UMKC Law Review 73, pp. 681 - 713.

DE PuRY, D., H. Hauser and B. SChMid (1995), Mut zum Aufbruch: Eine wirtschaftspolitische Agenda für die Schweiz, Orell Füssli, Zürich.

QuinET, E. (2004), A Meta-Analysis of Western European External Costs Estimates, Transportation Research D 9 (2004), pp. 465 - 476.

RAWLS, J. (1971), A Theory of Justice, Harvard University Press, Cambridge (Mass.).

Rebonato, R. (2012), Taking Liberties: A Critical Examination of Libertarian Paternalism, Palgrave Macmillan, Houndsmill, Basingstoke, UK.

Rebonato, R. (2013), A Critical Assessment of Libertarian Paternalism, mime, Oxford University, October.

Rhitalia, A., C. MCDAVID, S. SueKarRan, L. MYERS and A. SNOWDOn (2009), Impact of Presumed Consent for Organ Donation on Donation Rates: A Systematic Review, British Medical Journal 338, pp. $284-287$.

Rizzo, M. J., and G. Whiteman (2009), The Knowledge Problem of New Paternalism, Brigham Young University Law Review XX, pp. 905 - 968.

Rizzo, M. J., and G. Whiteman (2009a), Little Brother is Watching You: New Paternalism on the Slippery Slope, Arizona Law Review 51, pp. 685 - 739.

SACHA, S. C. (2007), Father Knows Best: A Critique of Joel Feinberg's Soft Paternalism, Georgia State University, Philosophy Thesis 17, http://digitalarchive.gsu.edu/cgi/viewcontent.cgi?article=1016\&context=philosophy_theses.

W. SAmuelson and R. ZeCKhauser (1988), Status Quo Bias in Decision Making, Journal of Risk and Uncertainty 1 (1988), pp. 7-59.

Schelling, T. C. (1978), Egonomics, or the Art of Self-Management, American Economic Review, Papers and Proceedings 68.2, pp. 290 - 294.

SCHELling, T. C. (1980), The Intimate Contest for Self-Command, Public Interest 60, pp. 94 - 118.

SCHMIDT, K. (1988), Mehr zur Meritorik: Kritisches und Alternatives zu der Lehre von den öffentlichen Gütern, Zeitschrift für Wirtschaft- und Sozialwissenschaften 108, pp. 383 - 403.

SCHNELlEnBACH, J. (2011), Wohlwollendes Anschubsen: Was ist mit liberalem Paternalismus zu erreichen und was sind seine Nebenwirkungen?, Perspektiven der Wirtschaftspolitik 12. pp. 445 459.

SCHNELLENBACH, J. (2012), Nudges and Norms: On the Political Economy of Soft Paternalism, European Journal of Political Economy 28, pp. 266 - 277.

Seliger, E., and K. P. Whyte (2012), Nudging Cannot Solve Complex Policy Problems, European Journal of Risk Regulation 1/2012, pp. 26 - 31.

SEN, A. K. (1977), Rational Fools: A Critique of the Behavioural Foundations of Economic Theory, Philosophy and Public Affairs 6, pp. 317 - 344.

SHAFER-LANDAU, R. (2005), Liberalism and Paternalism, Legal Theory 11, pp. 169 - 191. 
STOCKÉ, V. (2002), Framing und Rationalität: Die Bedeutung der Informationsdarstellung für das Entscheidungsverhalten, Oldenbourg, Munich.

Sugden, R. (2008), Why Incoherent Preferences Do Not Justify Paternalism, Constitutional Political Economy 19, pp. 226 - 248.

Sunstein, C. R., and R. H. ThaleR (2003), Libertarian Paternalism Is Not an Oxymoron, University of Chicago Law Review 70, pp. 1159 - 1202.

Thaler, R. H. (1992), The Winner's Curse, Paradoxes and Anomalies of Economic Life, Princeton University Press, Princeton N.J.

ThaleR, R. H., and S. BENARTZI (2004), Save More Tomorrow: Using Behavioral Economics to Increase Employee Saving, Journal of Political Economy 112, pp. S164 - S187.

Thaler, R. H., and C. R. Sunstein (2003), Libertarian Paternalism, American Economic Review (Papers and Proceedings) 93.2, pp. $175-179$.

THALER, R. H., and H. M. SHEFrin (1981), An Economic Theory of Self-Control, Journal of Political Economy 89, pp. 392 - 406.

ThAlER, R. H., and C. R. SUNSTEIN (2008), Nudge: Improving Decisions about Health, Wealth, and Happiness, Yale University Press, New Haven, CT.

TIETZEL, M., and C. MÜLLER (1998), Noch mehr zur Meritorik, Zeitschrift für Wirtschafts- and Sozialwissenschaften 118, pp. 87 - 127.

TVersky, A., and D. Kahneman (1981), The Framing of Decisions and the Psychology of Choice, Science 211, pp. $453-458$.

TVERSKY, A., and D. KAHNEMAn (1987), Rational Choice and the Framing of Decisions, in: R.M. Hogarth and M.W. Reder (eds.), Rational Choice: The Contrast Between Economics and Psychology, Chicago University Press, Chicago, pp. $67-94$.

WiCKSELL, K. (1896), Über ein neues Prinzip der gerechten Besteuerung, in: K. WiCKSELL, Finanztheoretische Untersuchungen, Gustav Fischer, Jena, pp. 76 - 164; English translation: A New Principle of Just Taxation, in: R. E. Musgrave and A. T. PEACOCK (eds.), Classics in the Theory of Public Finance, MacMillan, London et al. 1964, pp. 72 - 118.

WisDOM, J., J. S. DownS and G. LoEWENSTEIN (2010), Promoting Health Choice: Information versus Convenience, American Economic Journal: Applied Economics 2, pp. 164 - 178.

Withers, G. A, (1979), Private Demand for Public Subsidies: An Econometric Study of Cultural Support in Australia, Journal of Cultural Economics 3, pp. 53 - 61.

Whiteman, G. (2006), Against the New Paternalism: Internalities and the Economics of Self-Control, Policy Analysis Nr. 563, Cato Institute, 22. February.

Whiteman, G., and M. J. Rizzo (2007), Paternalist Slopes, New York University Journal of Law and Liberty 2, pp. $411-443$. 